(C) Cambridge University Press 2016. This is an Open Access article, distributed under the terms of the Creative Commons Attribution licence (http://creativecommons.org/licenses/by/4.0/), which permits unrestricted re-use, distribution, and reproduction in any medium, provided the original work is properly cited.

\title{
Oviposition site selection and survival of susceptible and resistant larvae of Helicoverpa armigera (Lepidoptera: Noctuidae) on Bt and non-Bt cotton
}

\author{
T.T.A. Luong ${ }^{1 *}$, S.J. Downes ${ }^{2}$, B. Cribb ${ }^{1,3}$, L.E. Perkins ${ }^{1}$ \\ and M.P. Zalucki ${ }^{1}$ \\ ${ }^{1}$ School of Biological Sciences, The University of Queensland, Brisbane 4072, \\ Australia: ${ }^{2}$ CSIRO Agriculture, Australian Cotton Research Institute, \\ Narrabri 2390, Australia: ${ }^{3}$ Centre for Microscopy \& Microanalysis, The \\ University of Queensland, Brisbane 4072, Australia
}

\begin{abstract}
In Australia Bt cotton has been planted since 1996, and has greatly improved the control of its key target Helicoverpa armigera (Hübner). There is no strong evidence that genetically modified cotton has been selected for significant physiological resistance to Bt toxin in field populations. There are many possible explanations for the lack of apparent selection that range from high compliance with the resistance management strategy for this technology to a lack of behavioral preference in key traits such as oviposition that could favor survival. To date most experiments that test oviposition of $H$. armigera on Bt cotton vs. conventional cotton have been done with susceptible moths. We determine the oviposition preference of a field isolated $\mathrm{Bt}$ resistant line of $H$. armigera and a susceptible counterpart when given a choice of non-Bt cotton and Bt-cotton with the same genetic background, and test whether there is any relationship between oviposition site selection (different plant structures) and the survival of the first instar larvae. Within cotton plants, our experiments consistently showed that both resistant and susceptible moths did not choose plants or plant parts that were less toxic in terms of Bt toxin on which to lay eggs. There was one exception in that susceptible moths were more likely to lay eggs on squares of $\mathrm{Bt}$ cotton plants than squares of non-Bt cotton. As expected, the mortality of susceptible $H$. armigera neonates was significantly higher on structures of Bt cotton plants than on those structures of conventional cotton, and survival was greater on flowers than on other structures of Bt cotton. This confirms opportunities for selection for resistance, and demonstrates no advantage in this respect to carrying resistance genes that might overcome the Bt toxins.
\end{abstract}

Keywords: oviposition preference, larval survival, behavioral resistance, resistant, susceptible

(Accepted 14 April 2016; First published online 5 July 2016)

*Author for correspondence

Phone: +84942 474474

Fax: +84573841214

E-mail: luong.tuyet@pyu.edu.vn

\section{Introduction}

Helicoverpa armigera (Hübner) (Lepidoptera: Noctuidae) is an economically important polyphagous pest that causes major damage and poor yields to a range of agricultural crops (Zalucki et al., 1986, 1994), particularly cotton, maize, 
legumes and tomato (Sharma, 2005). To control this pest chemical pesticides have been used extensively, but they cause undesirable side effects including resistant insects (Fitt, 2003). The management of pesticide resistance is now a necessity when both chemical sprays and crops engineered to express toxins are used (Forrester et al., 1994; Tabashnik et al., 2005, 2009; Tabashnik \& Carriére, 2010; Zhang et al., 2011). In Australia, cotton genetically modified to express the deltaendotoxin genes of Bacillus thuringiensis subsp. kurstaki (Bt) has been planted since the mid-1990s to control H. armigera and the native Helicoverpa punctigera (Wallengren), and has reduced insecticide usage from $30 \%$, for the first generation single toxin varieties (Fitt, 2008), to $85 \%$ for the second generation dual toxin varieties (Wilson et al., 2013). Bt cotton was quickly adopted by growers and now comprises nearly $90 \%$ of all cotton crops (Zalucki et al., 2009). Although it has greatly improved the control of $H$. armigera, the threat of an increasing frequency of insects that are physiologically resistant to the toxins remains (Downes et al., 2010).

The effects of the widespread planting of Bt cotton on $H$. armigera biology and ecology are generally unknown and potentially large. This major crop has become an effective population sink (Rochester et al., 2002; Baker et al., 2016). Zalucki et al. (2012) showed that there was no evidence that host selection by $H$. armigera among tobacco, conventional cotton, and cabbage had changed since the widespread adoption of genetically modified cotton in Australia. However, Zalucki et al. (2012) carried out their experiments with susceptible moths, and did not include Bt cotton in their oviposition assays. In the USA, Torres \& Ruberson (2006) suggested that Heliothis virescens (Fabricius) (Noctuidae) and Helicoverpa zea (Boddie) (Noctuidae) did not show an oviposition preference when offered non-Bt cotton and Bt cotton. They found a similar spatial distribution of eggs within plants between the two types of cotton in both pest species suggesting that moths had not changed their oviposition behavior despite variation in toxin concentration amongst structures within Bt cotton plants. Kumar \& Stanley (2010) found no discrimination by $H$. armigera moths between $\mathrm{Bt}$ and non-Bt cotton in a field study in India. Nevertheless, there is evidence that $H$. armigera shows behavioral avoidance through oviposition site selection that effectively circumvents exposure to toxin on Bt cotton plants (Men et al., 2005; Liu et al., 2010). In China there is evidence for oviposition non-preference for Bt cotton, which would reduce selection for physiological resistance (Zhao et al., 2016). Moths preferred to oviposit on non-Bt cotton in mixed plantings of Bt and non-Bt cotton (Liu et al., 2010). In Gujarat, India, egg density was reduced with increasing Bt cotton patch size (Lodaya \& Borad, 2014). The total number of eggs deposited on conventional cotton plants was about $95 \%$ greater than that on $\mathrm{Bt}$ cotton plants at bud-flower stage and flower-boll stage (Lodaya \& Borad, 2014).

Extensive work on various aspects of oviposition behavior has been conducted on Australian populations of $H$. armigera (reviewed in Cunningham \& Zalucki, 2014). However to date those experiments were carried out using susceptible H. armigera moths. Experiments that compare oviposition behavior of H. armigera moths that are physiologically resistant vs. susceptible to Bt cotton will clarify an important potential impact on resistance evolution: whether shifts in adult and larval behavior exist that might lead to differential survival of these genotypes on Bt cotton plants.

Here we determine the oviposition preference of $H$. armigera from colonies that are resistant and susceptible to Bt-toxin when given a choice of Bt and non-Bt cotton plants by asking: (1) whether females choose oviposition sites randomly or lay more eggs on plants (e.g. non-Bt cotton) that are potentially less toxic; we also ask (2) whether moths from the different strains choose less toxic parts within plants with respect to Bt expression. We base plant part toxicity on a review of published data. Finally we determine (3) whether there is any relationship between oviposition sites and the survival of the first instar larvae of the two $H$. armigera strains (susceptible and resistant) on different plant structures (young leaf, mature leaf, stem, square and flower) on both Bt cotton and non-Bt cotton. Survival experiments were examined using laboratory assays.

\section{Materials and methods}

\section{Insects}

The H. armigera Bt-resistant strain used in this study (SP15) was established from a single mating pair collected as eggs on corn near Griffith, NSW, in December 2002. Progeny from the pair were subjected to an $F_{2}$ screen (Andow \& Alstad, 1998) and the SP15 colony was formed from $\mathrm{F}_{2}$ offspring that survived a discriminating dose (LD 95) $\left(1 \mathrm{ug} \mathrm{cm}^{-2}\right)$ of Cry2Ab (Mahon et al., 2007). The $\mathrm{F}_{2}$ screens were performed with the specific intention of detecting resistance to Cry toxins in $H$. armigera. SP15 initially possessed a very restricted gene pool as it originated from a single isofemale line. Lepidopteran colonies suffer severe inbreeding depression rapidly leading to a loss of vigor that strongly influences the outcome of bioassays. Consequently, over the years since its isolation SP15 has been outcrossed to the susceptible strain, GR, numerous times, to maintain fitness and to produce a strain that is near isogenic with the susceptible strain (Mahon et al., 2007). Following each outcross, the colony was maintained without selection for one generation and then reselected with 1-2 ug cm ${ }^{-2} \mathrm{Cry} 2 \mathrm{Ab}$ toxin as a diet surface treatment. Dried and ground corn (Zea mays L.) leaf material was used as a source of Cry2Ab toxin. Corn powder was provided by Monsanto (St Louis, USA) as a lyophilized leaf powder. This powder contained the transgenically expressed $B$. thuringiensis crystal protein $\mathrm{Cry} 2 \mathrm{Ab}$, at a concentration of $6 \mathrm{mg} \mathrm{g}^{-1}$ powder (Mahon et al., 2007). Toxin in the leaf was calibrated using an enzyme-linked immune-sorbent assay (ELISA) method on aliquots of leaf material after freeze-drying and homogenization. ELISA methods and protein extraction are detailed in Holt et al., (2002). All subsequent generations were selected at this dose. Moths used to establish a susceptible $H$. armigera colony were collected from the field from a range of crops such as chickpea, pigeon pea, cotton, etc., and bulk mated to form a colony. All colonies were maintained at the Australian Cotton Research Institute, Narrabri, New South Wales.

Resistant (SP15) and susceptible (GR) eggs of H. armigera were transferred to the laboratory of the School of Biological Science at The University of Queensland, Australia to establish colonies for experiments. Neonates were individually reared on artificial diet (modified from Teakle \& Jensen, 1985) until the 3rd-instar stage in 45-well plastic trays (circular well: $23 \mathrm{~mm}$ in diameter, $18 \mathrm{~mm}$ in height; Tacca Plastics Australia Pty Ltd., Moorebank, NSW, Australia) at which time they were transferred to 32-well plastic trays (square well: $30 \mathrm{~mm}$ in width, $20 \mathrm{~mm}$ in height; Tacca Plastics Australia Pty Ltd.). The larvae remained in the 32-well trays 
during pupation. Rearing trays were covered and heat-sealed with a perforated lid. Male and female pupae were separated and each sex was housed in bulk in vermiculite in an incubator at $25^{\circ} \mathrm{C}( \pm 1)$ and $80 \%$ relative humidity $(\mathrm{RH})( \pm 1)$ to ensure synchronous adult emergence. Fifteen male and fifteen female moths were released together in each plastic holding container $(20 \mathrm{~cm}$ in width $\times 20 \mathrm{~cm}$ in length $\times 30 \mathrm{~cm}$ in height) covered securely with polypropylene nappy liners as a substrate for egg laying. Moths were provided with a pot $(\sim 30 \mathrm{ml})$ of $10 \%$ honey/sugar solution fed through a cotton wick as a food source.

The susceptible and resistant colonies were tested at least monthly for their responses to Bt toxin as part of a program monitoring populations for resistance. Only families that were confirmed to not be resistant by screening were incorporated into the susceptible colony.

\section{Plants}

A transgenic cotton cultivar containing Cry genes and a conventional cotton variety with the same genetic background as the transgenic variety but without the Cry genes were used in experiments. Conventional cotton (Sicot $71 \mathrm{R}$ : hereafter 'non-Bt') and Bollgard II ${ }^{\circledR}$ cotton (Sicot 71 BR: hereafter 'Bt cotton') were used to test oviposition preference. A pool of plants was prepared as follows. Three seeds were sown in each pot (30 cm in height and $25 \mathrm{~cm}$ in diameter) in UC soil mix (a mixture of sand, bark and peat moss). After 2-weeks the healthiest seedling was retained and the others removed by hand. Plants were maintained in a greenhouse at The University of Queensland at $24 \pm 6^{\circ} \mathrm{C}$ and $56 \pm 10 \% \mathrm{RH}$. All plants were watered three times a week and supplied with a general purpose soluble fertilizer (Thrive 16: 9: 12: $2 \mathrm{MgO}$ ) every 4 weeks. Similar sized (50-60 cm in height) plants at the same stage of development: open flowers, squares and bolls present, were used in oviposition choice tests.

\section{Oviposition preference}

Experiments were run four times from December 2012 to April 2014 with eight cages (replicates) in total for each of two strains (table 1). There were 108 cotton plants used for each larval strain and more than 240 female moths used in total. Experiments were staged as follows: December 2012 for replicates 1 and 2, July 2013 for replicate 3, November 2013 for replicates 4, 5, and 6, and April 2014 for replicates 7 and 8 . One day after eggs started to be laid in holding containers, each group of 30 moths (15 males and 15 females) were released into a large cage $(180 \mathrm{~cm} \times 180 \mathrm{~cm} \times 180 \mathrm{~cm})$, which contained cotton plants in a glasshouse. There were 12-16 plants in each cage; $6-8 \mathrm{Bt}$ cotton and 6-8 non-Bt cotton plants arranged randomly. Pots with $10 \%$ sucrose-solution were placed in a plastic box with water within the cage to supply additional nutrients for the insects. Moths were acclimated to the cage environment and allowed to lay eggs for two nights. On the second day, moth survival was checked. If moths had died, more moths were added from the laboratory culture to keep a total of 30 moths (15 males and 15 females) in each cage. All eggs laid within two nights were removed from plants so that they would be clean to use in experiments on the following day. The location of plants was re-randomized daily to reduce position effects. Eggs were counted once, on the next day. The number of eggs on each plant structure: immature leaf, mature leaf, stem, square, or flower was counted for 1 day.

In the third replicate (July 2013) plants of two varieties (Bt and non-Bt cotton) were not synchronous in their development. Although plants across treatments were the same height, those that were Bt cotton had 3-4 nodes more than those that were non-Bt cotton. In this experiment, across both insect genotypes the number of eggs laid on $\mathrm{Bt}$ cotton (355 eggs plant ${ }^{-1}$ ) was significantly higher than the number laid on non-Bt cotton (143 eggs plant ${ }^{-1}$ ) (table 1$)$. Thus, this third replicate was not used further in statistical analysis. For all other experiments plants were of similar height and at the same developmental stage.

\section{Survival of newly hatched larvae}

Experiments were performed in a temperature-controlled room set at $25 \pm 1^{\circ} \mathrm{C}$ and with a natural light cycle. Neonates were placed in round plastic containers $(120 \mathrm{~mm}$ diameter $\times$ $98 \mathrm{~mm}$ height) with each plant structure to assess the survival of newly hatched larvae. Each container had a small pot (height $33 \mathrm{~mm}$, top diameter $44 \mathrm{~mm}$, base diameter $31 \mathrm{~mm}$ ) with water to keep the plant parts fresh for 2 days. A hole was made in the lid of each small pot and the stem attached to the plant part inserted. Large containers were open at the top and covered with polypropylene nappy liners secured around their lids for air circulation. There were four treatments (young leaf, mature leaf, square and flower) for each strain (SP15 and GR) with each cotton line (Bt and non-Bt). Ten neonates were introduced into each treatment and left for 2 days. Ten replicate experiments were performed for each plant part of cotton line and larval strain. After 2 days, surviving larvae were counted and introduced to artificial diet to test their survival after a further 4 days (i.e., to 6 days of age).

\section{Data analysis}

Statistical analyses were performed using the Statgraphic Century procedure, version 15.1 (Statpoint Technologies, Inc., Washington D.C., USA). As total egg numbers varied greatly between cages (see the section Results), the data were expressed as percentage of the total egg lay on each plant. All data recorded as a percentage were arcsin-transformed to correct heterogeneity of variances prior to analysis using an analysis of variance (ANOVA) with strains and plant lines as main effects. Differences in the distribution of eggs between the two moth strains on parts within Bt vs. non-Bt cotton plants was analyzed using Wilcoxon Signed-Rank Tests. Oviposition preference and larval survival between $\mathrm{Bt}$ and conventional cotton of the two moth strains were analyzed using a two-way ANOVA. The mean percentage of oviposition preference on different plant structures and the mean percentages of larval survival on different positions of plant were analyzed with Tukey's Multiple Range Tests.

\section{Results \\ Oviposition preference}

Data for 7 out of the 8 replicates were used in the analysis of preference since in one of the replicates the plants were at different phonological stages (see the section Methods). There were no significant differences in oviposition percentages between resistant and susceptible moths $(\mathrm{df}=1, F=1.89$, 
Table 1. The mean $( \pm \mathrm{SE}$ ) of eggs per plant $(n=6$ or 8 ) laid by resistant or susceptible female moths on Bt cotton and non-Bt cotton plants in each cage $(n=8)$ from December 2012 to April 2014.

\begin{tabular}{|c|c|c|c|c|c|c|c|c|c|c|}
\hline \multirow[t]{2}{*}{ Strain } & \multirow[t]{2}{*}{ Cotton } & \multirow[b]{2}{*}{1} & \multicolumn{8}{|c|}{ Cage } \\
\hline & & & 2 & 3 & 4 & 5 & 6 & 7 & 8 & Mean $( \pm S E)$ \\
\hline Resistant & $\mathrm{Bt}$ & $53 \pm 6 a$ & $21 \pm 3 a$ & $355 \pm 40 a$ & $71 \pm 7 a$ & $10 \pm 3 a$ & $4 \pm 2 \mathrm{a}$ & $14 \pm 2 a$ & $143 \pm 29 a$ & $84 \pm 42 a$ \\
\hline \multirow[t]{2}{*}{ Susceptible } & $\mathrm{Bt}$ & $22 \pm 12 b$ & $64 \pm 10 b$ & $130 \pm 11 c$ & $8 \pm 2 b$ & $51 \pm 14 b$ & $57 \pm 16 b$ & $16 \pm 3 a$ & $40 \pm 11 b$ & $48 \pm 13 b$ \\
\hline & N-Bt & $18 \pm 5 b$ & $72 \pm 8 b$ & $88 \pm 11 d$ & $7 \pm 11 b$ & $40 \pm 11 b$ & $54 \pm 16 b$ & $19 \pm 3 a$ & $75 \pm 13 b$ & $47 \pm 11 b$ \\
\hline
\end{tabular}

Means within a column followed by same letter are not significantly different ( $\alpha=0.05$, Tukey's Multiple Range Test). The replicate with plants at different growth stages is highlighted.

$P=0.17)$. Both resistant and susceptible moths did not discriminate between $\mathrm{Bt}$ and non-Bt cotton (resistant: $\mathrm{df}=1$, $F=0, P=0.97$; susceptible: $\mathrm{df}=1, F=0.29, P=0.59$ ). The percentage of eggs that resistant moths laid on Bt cotton plants was equal to those on non-Bt cotton plants (50\% on each). The results were similar with susceptible moths $(48 \%$ on $\mathrm{Bt}$ cotton and $52 \%$ on non-Bt cotton) (fig. 1).

There was no difference in egg distribution of resistant moths with respect to parts within a plant for Bt and non-Bt cotton; young leaf $(t=0.84, P=0.40)$, mature leaf $(t=0.09, P=0.92)$, square $(t=-0.52, P=0.60)$, stem $(t=-1.34$, $P=0.18)$, and flower $(t=1.17, P=0.24)$. Oviposition of susceptible moths was not different between $\mathrm{Bt}$ and non-Bt cotton on most structures of cotton plants including young leaves $(0.84$ $P=0.40)$, mature leaves $(t=-1.31, P=0.19)$, stems $(t=0.18$, $P=0.85)$, and flowers $(t=-1.41, P=0.16)$. The exception was that susceptible moths laid significantly more eggs on squares of $\mathrm{Bt}$ cotton compared with non-Bt cotton plants $(t=2.21$, $P=0.03 ; 8$ and $5 \%$, respectively).

\section{Survival}

\section{Two-day survival}

There was no effect of cotton plant line (Bt vs. non-Bt) on survival of resistant neonates amongst plant structures: young leaf $(\mathrm{df}=1,1 F=1.92, P=0.18)$, mature leaf $(\mathrm{df}=1,1$, $F=3.44, P=0.08)$, square $(\mathrm{df}=1,1, F=0.83, P=0.37)$, and flower ( $\mathrm{df}=1,1, F=0.00, P=1.00)$ after 2 days. Overall survival of resistant larvae was $75 \%$ on $\mathrm{Bt}$ cotton and $81 \%$ on non-Bt cotton plants. However, cotton line did have a significant effect on the survival of susceptible neonates; $59 \%$ of larvae survived on Bt cotton for 2 days in comparison with $81 \%$ on non-Bt cotton. The survival of susceptible larvae was significantly different on young leaves $(\mathrm{df}=1,1 F=22.81$, $P=0.0002)$, mature leaves $(\mathrm{df}=1,1, F=19.55, P=0.0004)$, and squares $(\mathrm{df}=1,1, F=11.52, P=0.004)$ of the two cotton lines (fig. 2). In contrast, there was no significant difference in percentages of susceptible neonates surviving on the flowers of Bt vs. non-Bt cotton ( $\mathrm{df}=1,1, F=3.38, P=0.08)$. Larval survival on flowers was significantly higher than on young leaves, mature leaves and squares $(\mathrm{df}=3, F=3.62, P=0.02)$ of Bt cotton plants. In general, the survival of resistant and susceptible larvae on non-Bt cotton was similar. Resistant larvae, however, survived better on Bt cotton plants than susceptible larvae, and there was no difference amongst plant parts or cotton lines. For susceptible larvae survival was generally poorer on Bt cotton but was better on squares and flowers than other Bt cotton structures (fig. 2).

\section{Six-day survival}

The larvae alive after 2 days exposure to plant parts were moved onto artificial diet and assessed again at 6 days of age. The cotton line that larvae were initially exposed to did not affect the survival of resistant larvae after a further 4 days on diet. The percentage of resistant larvae surviving on non-Bt cotton structures appeared higher than that on Bt cotton plant parts (63 and 59\%, respectively), but was not significantly different $(\mathrm{df}=1, F=0.40, P=0.59)$. There was no significant difference between $\mathrm{Bt}$ and non-Bt cotton in the number of resistant larvae surviving on diet after being exposed to cotton plant structures: young leaf $(\mathrm{df}=1, F=2.59$, $P=0.25)$, mature leaf $(\mathrm{df}=1, F=5.49, P=0.94)$, square $(\mathrm{df}=1$, $F=0.01, P=0.94)$, and flower $(\mathrm{df}=1, F=0.54, P=0.54)$.

After 4 days on diet, the percentages of susceptible larvae surviving declined sharply after initial exposure to several plant structures of Bt cotton plants: young leaves (from 50 to $25 \%$ ), mature leaves (from 53 to $25 \%$ ) and squares (from 63 to $38 \%$ ) but less so on flowers (from 70 to $47 \%$ ). These differences were statistically significant among plant structures of Bt cotton plants ( $\mathrm{df}=3,36, F=3.62, P=0.02)$ (fig. 3). There was no significant difference in survival of susceptible larvae on diet after 4 days after initial exposure to non-Bt cotton structures $(\mathrm{df}=3,35, F=0.52, P=0.67)$ and their average survival decreased by about $14 \%$ after 4 days, similar to resistant larvae. The number of surviving susceptible larvae after 4 days on diet was significantly different after initial exposure to Bt vs. non-Bt cotton plant parts: young leaves $(\mathrm{df}=1, F=835$, $P=0.001)$, mature leaves ( $\mathrm{df}=1, F=65.11, P=0.02)$, squares ( $\mathrm{df}=1, F=25.14, P=0.04)$; the exception was flowers $(\mathrm{df}=1$, $F=15.38, P=0.06$ ).

As expected, after 4 days on diet susceptible larvae initially exposed to Bt cotton structures had lower survival than those initially exposed to non-Bt cotton and survival was higher on squares and flowers of Bt cotton. The average survival of susceptible larvae decreased by $25-28 \%$ on young leaves, mature leaves and squares of Bt cotton. By contrast, the overall survival of resistant larvae amongst structures on $\mathrm{Bt}$ and non-Bt cotton plants was similar after 2 days and 6 days.

\section{Discussion}

The oviposition experiments were run over a 2-year period in different weather condition, thus the numbers of eggs per plant were highly variable. The results of oviposition preference experiments showed that resistant and susceptible moths behaved similarly when laying eggs on Bt and non-Bt cotton. Both $\mathrm{Bt}$ and conventional cotton with the same genetic 

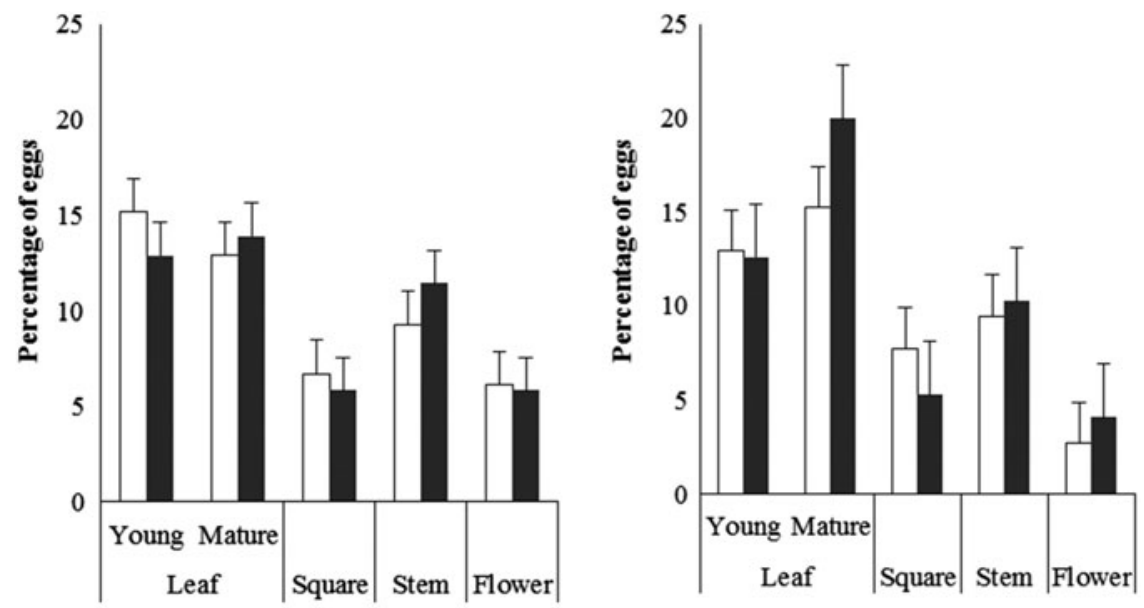

Fig. 1. Mean percentages $( \pm S E)$ of eggs that resistant (left) and susceptible (right) female moths laid on different plant structures on Bt cotton (white bars) and non-Bt cotton (black bars) plants.
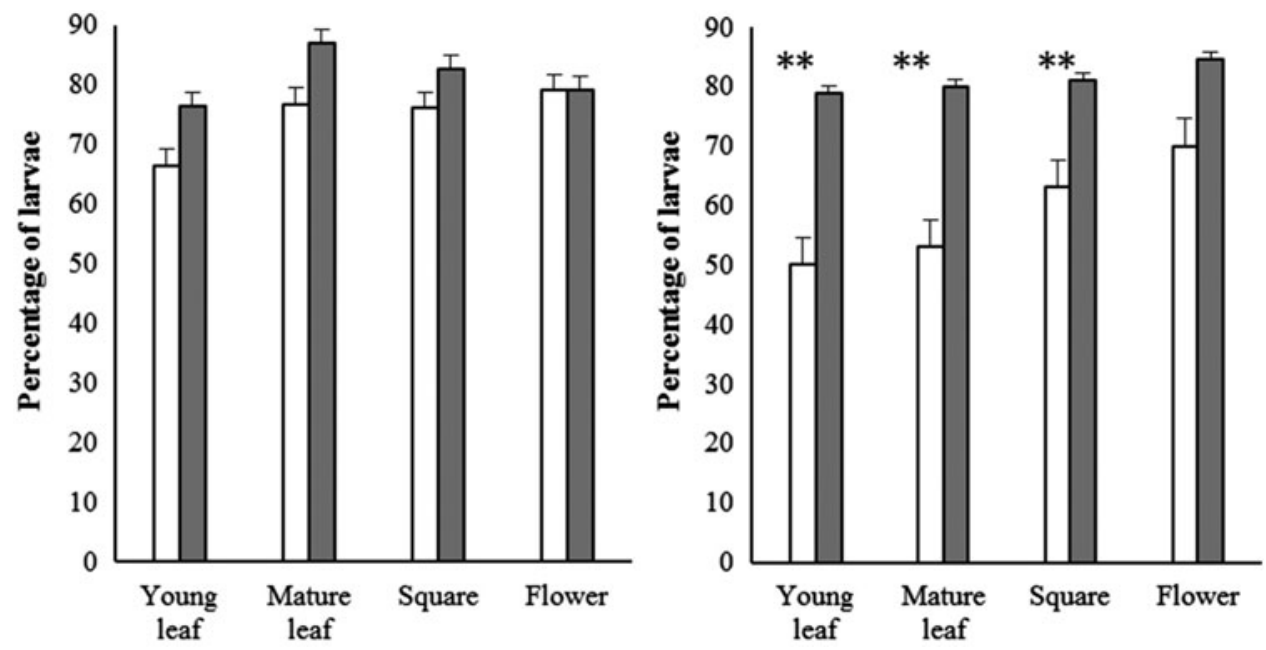

Fig. 2. Mean percentages ( \pm SE) of resistant (left) and susceptible (right) larvae that survived on plant parts (young leaf, mature leaf, square, and flower) of Bt cotton (white) and non-Bt cotton (grey) after 2 days. Asterisks identified the significant difference in survival of susceptible neonates on flowers between Bt cotton and non-Bt cotton.

background were equally likely to receive eggs. The percentages of eggs that resistant and susceptible moths laid on $\mathrm{Bt}$ and non-Bt cotton were not significantly different suggesting that the two moth strains did not discriminate between Bt and non-Bt cotton plants or could distinguish them; they did not prefer one over the other. Stage of plant is important when making comparisons (Firempong \& Zalucki, 1990). In one of our experiments, Bt cotton was further developed with more flower/fruiting structures, and even though both plant types were similar in height, the Bt plants received more eggs (see the section Methods). The result highlights that assays assessing host preference for Bt vs. non-Bt cotton must be carefully controlled.

Within cotton plants, we found that females consistently chose oviposition sites with little regard to the toxicity of plant parts. Most eggs were laid on leaves, especially young leaves, which are more toxic than squares on Bt cotton (Greenplate, 1999; Adamczyk et al., 2001a; Gore et al., 2001).
The results of these experiments corroborated previous studies (Zalucki et al., 1986; Jallow et al., 1999), which showed that Helicoverpa spp. moths preferred to lay eggs on rough or hairy surfaces (young leaves are usually the hairiest). Pink bollworm, Pectinophora gossypiella (Saunders) from susceptible and resistant strains also did not discriminate between $\mathrm{Bt}$ and non-Bt cotton bolls indicating that oviposition was independent of susceptibility to Cry1Ac (Liu et al., 2002). Torres \& Ruberson (2006) found that the numbers of Helicoverpa spp. eggs per plant were similar on both cotton types (Bt and non-Bt cotton), and on average approximately $80-95 \%$ of eggs were laid on top nodes of both types of cotton. The percentages of eggs on squares, stems and flowers were not significantly different. These results confirmed that both resistant and susceptible moths generally did not choose plant parts that were less toxic in terms of Bt toxin on which to lay eggs. There was an exception; the percentages of eggs from susceptible moths on squares were significantly different 

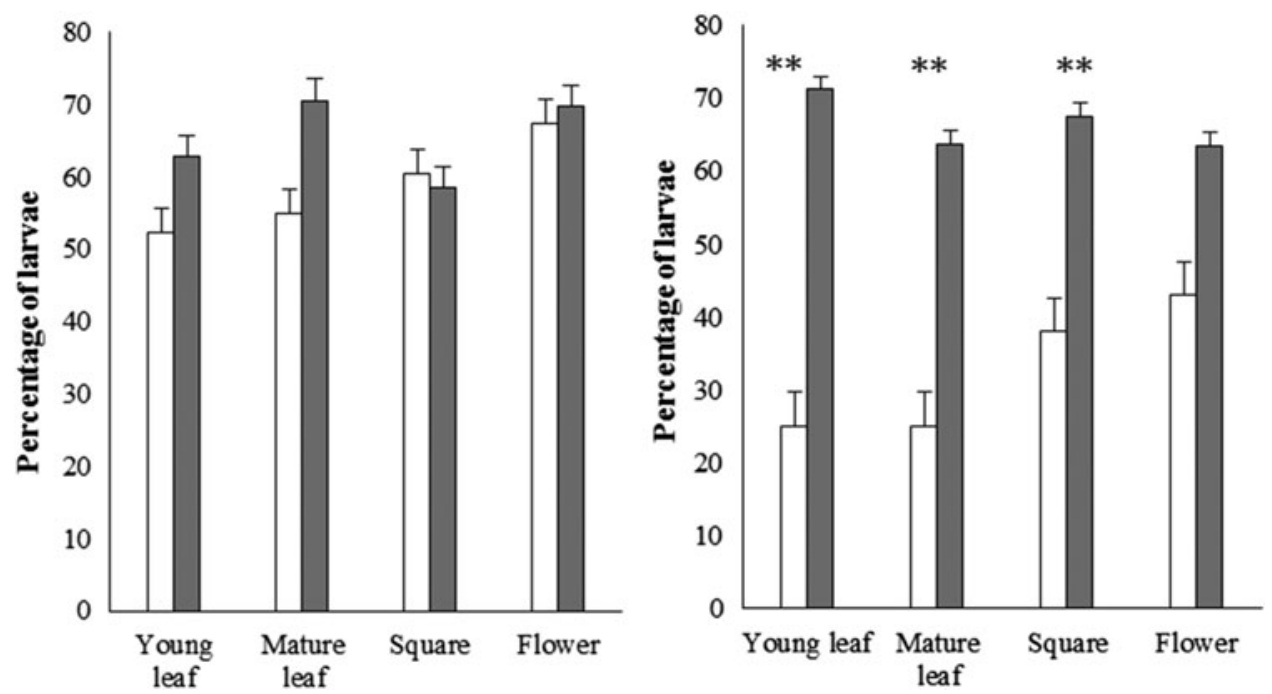

Fig. 3. Mean percentages $( \pm$ SE) of resistant (left) and susceptible (right) larvae that survived on artificial diet after 6 days; 2 days on plant parts (young leaf, mature leaf, square, and flower) of Bt cotton (white) and non-Bt cotton (grey) followed by 4 days artificial diet. Asterisks identified the significant difference in survival of susceptible neonates on flowers between Bt cotton and non-Bt cotton.

between Bt and non-Bt cotton plants. Significantly more eggs were laid on squares of Bt cotton than squares of non-Bt cotton and could offer a chance for susceptible larvae to survive on $\mathrm{Bt}$ cotton plants since these sites become flowers that are known to express less toxin (Gore et al., 2001).

As expected, data from the larval survival assay demonstrates that mortality of susceptible $H$. armigera neonates is significantly higher on different structures (young leaves, mature leaves, and squares) of Bt cotton plants compared with non-Bt cotton. These results are consistent with previous research (Gore et al., 2001; Kranthi et al., 2005; Arshad et al., 2009; Lu, 2010). The survival of $H$. zea larvae has been found to be higher on squares and flower anthers than on other floral structures on non-Bt and Bollgard $\mathrm{II}^{\circledR}$ cotton (Gore et al., 2001; Kranthi et al., 2005). Arshad et al., (2009) showed a significantly higher mortality in neonates fed on Bt cotton leaves than those fed on Bt flower-bolls. At the very small larval stage, susceptible larvae were more likely to be found alive on flowers of Bollgard $\mathrm{II}^{\circledR}$ cotton suggesting these plant components are likely to have relatively low levels of Bt toxin (Yang et al., 2008). The apparent preference for flowers by susceptible larvae may be related to the expression of Cry proteins between structures. Levels of Cry1Ac expression in Bollgard ${ }^{\circledR}$ cotton plants are typically higher on vegetative tissues compared with floral structures, such as pollen and flower petals (Greenplate, 1999; Adamczyk et al., 2001b; Gore et al., 2001). In Australian growing conditions, Lu (2010) confirmed that levels of Cry1Ac expression were highest in leaves and lower in squares and flowers; but Bt toxin was not uniform within square and flower parts; the expression of Cry 1Ac was highest in bracts followed by petals, and lowest in anthers. The fact that flowers overall expressed low levels of Bt toxin was supported by the finding in our study that there was no significant difference in percentages of susceptible neonates surviving on the flowers of Bt vs. non-Bt cotton. Low levels of expression in Bollgard $\mathrm{II}^{\circledR}$ cotton squares and flowers offer an opportunity for neonates to survive if they are able to move and find plant parts with low levels of Bt toxin. Given the oviposition pattern of moths, which would result in more eggs being laid on squares, hatching larvae could survive better than expected at the flowering stage if they fed on such plant parts.

In general, adults of both strains did not differentiate between and within plant structures with respect to $\mathrm{Bt}$ expression, except for susceptible moths laying more eggs on squares. Depositing a higher percentage of eggs on squares may lead to higher survival of larvae on flowers as they develop. Fifteen per cent of eggs were laid on Bt squares. Seventy per cent of those could survive on Bt flowers after 2 days and these larvae continued to survive at a high rate $(43 \%)$ after 4 days when moved onto artificial diet with no toxin. In total, 6-7\% of larvae could survive on Bt cotton if they found a non-toxic or less-toxic food at the first instar stage. Current thresholds for chemical control of Bt cotton are two small larvae $(>3 \mathrm{~mm})$ per meter or one medium larva $(>8 \mathrm{~mm})$ per meter (Fitt, 2003). If $H$. armigera female moths laid 50 eggs plant ${ }^{-1}$, it is predicted that three larvae could survive on Bt cotton plants, therefore reaching the threshold for chemical spraying. Since the adoption of Bt cotton in Australia, the number of egg laid per plant has declined sharply and 50 eggs plant ${ }^{-1}$ is unlikely. But a combination of locally high egg load, at the right plant stage (squaring cotton), and larval movement may in part account for the 'high' level of non-resistant larvae seen occasionally. Lu et al. (2011) also suggested that $H$. armigera larvae movement might be an important part of the reason for survival. Their chances of survival on Bt cotton would increase if they moved away from plant parts with high toxin levels, such as leaves, to more suitable food, for example flowers (see Yang et al., 2008). Larvae may establish on plants with poorer expression before moving onto higher expression areas (Lu et al., 2011).

In conclusion, resistant and susceptible $H$. armigera female moths from Australia did not show differences in oviposition between Bt and non-Bt cotton plants in glasshouse experiments. Resistant and susceptible moths show broadly similar oviposition behaviour with some minor differences. In addition, the fact that some $20 \%$ of susceptible larvae survived 2 days exposure on Bt cotton plant parts after a further 4 days on artificial diet, suggests that they either avoided feeding 
and could survive for a period of starvation, or fed so little that they did not receive a fatal dose. Further experimentation would be useful to determine whether $H$. armigera larvae can: (1) detect Bt toxin, (2) survive a period of starvation, and/or (3) recover from a period of starvation.

\section{Acknowledgements}

The authors thank Tracey Parker (CSIRO Agriculture, Australian Cotton Research Institute, Narrabri, Australia) for supplying cotton seeds and $H$. armigera eggs for our experiments. Support for this project was provided by MOET (Vietnamese Government Scholarship), The University of Queensland, CSIRO, and The Cotton Research and Development Corporation.

\section{References}

Adamczyk, J.J., Adams, L.C. \& Hardee, D.D. (2001a) Field efficacy and seasonal expression profiles for terminal leaves of single and double Bacillus thuringiensis toxin cotton genotypes. Journal of Economic Entomology 94(6), 1589-1593. doi: http://dx.doi.org/10.1603/0022-0493-94.6.1589.

Adamczyk, J.J., Hardee, D.D., Adam, L.C. \& Sumerford, D.V. (2001b) Correlating differences in larval survival and development of bollworm (Lepidoptera: Noctuidae) and fall armyworm (Lepidoptera: Noctuidae) to differential expression of Cry1A(c)-Endotoxin in various plant parts among commercial cultivars of transgenic Bacillus thuringiensis Cotton. Journal of Economic Entomology 94(1), 284-290.

Adamczyk, J.J. \& Meredith, W.R. (2004) Genetic basis for variability of Cry1Ac expression among commercial transgenic Bacillus thuringiensis (Bt) cotton cultivars in the United States. Journal of Cotton Science 8(1), 17-23.

Andow, D.A. \& Alstad, D.N. (1998) F2 screen for rare resistance alleles. Journal of Economic Entomology 91(3), 572-572.

Arshad, M., Suhail, A., Arif, M.J. \& Khan, M.A. (2009) Transgenic-Bt and non-transgenic cotton effects on survival and growth of Helicoverpa armigera. International Journal of Agriculture and Biology 11(4), 473-476.

Baker, G.H., Leven, T., May, T. \& Tann, C.R. (2016) Planting window requirements for Bt cotton in Australia: do they limit the exposure of Helicoverpa spp. (Lepidoptera: Noctuidae) to Bt toxins? Austral Entomology 5(1), 32-42. doi: 10.1111/aen.12147.

Chen, Y., Wen, Y., Chen, Y., Cothren, J.T., Zhang, X., Wang, Y., Payne, W.A. \& Chen, D. (2012) Effects of extreme air temperature and humidity on the insecticidal expression level of Bt Cotton. Journal of Intergrative Agriculture 11(11), 1836-1844.

Cunningham, J.P. (2012) Can mechanism help explain insect host choice? Journal of Evolutionary Biology 25(2), 244-251. doi: 10.1111/j.1420-9101.2011.02435.x.

Cunningham, J.P. \& Zalucki, J.M. (2014) Understanding Heliothine (Lepidoptera: Heliothinae) pests: what is a host plant? Journal of Economic Entomology 107(1), 881-896. doi: http://dx.doi.org/10.1603/EC14036.

Cunningham, J.P., West, S.A. \& Zalucki, M.P. (2001) Host selection in phytophagous insects a new explanation for learning in adults. Oikos 95(3), 537-543.

Downes, S., Mahon, R.J., Rossiter, L., Kauter, G., Leven, T., Fitt, G. et al. (2010). Adaptive management of pest resistance by Helicoverpa species (Noctuidae) in Australia to the Cry2Ab Bt toxin in Bollgard $\mathrm{II}^{\circledR}$ cotton. Evolutionary Applications 3(5-6), 574-584. doi: 10.1111/j.1752-4571.2010.00146.x.
Firempong, S. \& Zalucki, M.P. (1990) Host plant selection by Helicoverpa armigera (Hübner) (Lepidoptera Noctuidae) role of certain plant attributes. Australian Journal of Zoology 37(6), 675-683.

Fitt, G.P. (2003) Implementation and impact of transgenic Bt cotton in Australia. pp. 371-381 in Proceedings of the third World Cotton Research by Cotton Production for the New Millennium, 913 March, 2003, Cape Town, South Africa.

Fitt, G.P. (2008) Have Bt crops lead to changes in insecticide use patterns and impacted IPM? pp. 303-328 in Romeis, J., Shelton, A.M. \& Kennedy, G.G. (Eds) Integration of InsectResistant Genetically Modified Crops Within IPM Programs, vol. 5. Dordrecht, Springer.

Forrester, N.W., Cahill, M., Bird, L.J. \& Layland, J.K. (1994) Management of pyrethroid and endosulfan resistance in Helicoverpa armigera (Lepidoptera: Noctuidae) in Australia. Bulletin of Entomological Research: Supplement Series 132 pp.

Gore, J., Leonard, B.R. \& Adamczyk, J.J. (2001) Bollworm (Lepidoptera: Noctuidae) survival on 'Bollgard' and 'Bollgard II' cotton flower bud and flower components. Journal of Economic Entomology 94(6), 1445-1451. doi: 10.1603/0022-0493-94.6.1445.

Greenplate, J.T. (1999) Quantification of Bacillus thuringiensis insect control protein Cry1Ac over time in bollgard cotton fruit and terminals. Journal of Economic Entomology 92(6), 1377-1377.

Holt, H.E., Mares, C. \& Akhurst, R.J. (2002) Determination of the Cry Protein content of Bt Transgenic Cotton a Technical Manual for Laboratory Use. Canberra, ACT, Australia, CSIRO Entomology, $13 \mathrm{pp}$.

Jallow, M.F.A., Zalucki, M.P. \& Fitt, G.P. (1999) Role of chemical cues from cotton in mediating host selection and oviposition behaviour in Helicoverpa armigera (Hübner) (Lepidoptera: Noctuidae). Australian Journal of Entomology 38(4), 359-366.

Kranthi, K.R., Naidu, S., Dhawad, C.S., Tatwawadi, A., Mate, K., Patil, E., Bharose, A.A., Behere, G.T., Wadaskar, R.M. \& Kranthi, S. (2005) Temporal and intra-plant variability of Cry1Ac expression in Bt-cotton and its influence on the survival of the cotton bollworm, Helicoverpa armigera (Hübner) (Noctuidae: Lepidoptera). Current Science 89(2), 291-298.

Kumar, R.K. \& Stanley, S. (2010) Comparative feeding behavior and ovipositional aspects of cotton bollworms Helicoverpa armigera on transgenic and non-transgenic cotton. Resistant Pest Management Newsletter 20(1), 26-28.

Liu, Y.B., Tabashnik, B.E., Dennehy, T.J., Carrière, Y., Sims, M.A. \& Meyer, S.K. (2002) Oviposition on and mining in bolls of Bt and non-Bt cotton by resistant and susceptible pink bollworm (Lepidoptera: Gelechiidae). Journal of Economic Entomology 95(1), 143-148. doi: 10.1603/0022-0493-95.1.143.

Liu, F., Xu, Z., Zhu, Y. C., Huang, F., Wang, Y., Li, H., Gao, C., Zhou, W. \& Shen, J. (2010) Evidence of field-evolved resistance to Cry1Ac-expressing Bt cotton in Helicoverpa armigera (Lepidoptera: Noctuidae) in northern China. Pest Management Science 66 (2), 155-161.

Lodaya, J. \& Borad, C. K. (2014) Evaluation of oviposition preference for different host crops by cotton bollworm, Helicoverpa armigera (Hubner) in Bt cotton dominated patch. Trends in Biosciences 7(24), 4442-4445.

Lu, B. (2010) Thresholds and mechanisms of survival for Bt-susceptible Helicoverpa spp. living on Bollgard $\mathrm{II}^{\circledR}$ cotton. (Doctor of Philosophy), University of New England, Armidale, NSW.

Lu, B., Downes, S., Wilson, L., Gregg, P., Knight, K., Kauter, G. \& McCorkell, B.C. et al. (2011) How do susceptible Helicoverpa larvae behave on Bollgard II? The Australian Cotton Grower 32 (6), 12-15. 
Mahon, R.J., Olsen, K.M., Garsia, K.A. \& Young, S.R. (2007) Resistance to Bacillus thuringiensis Toxin Cry2Ab in a Strain of Helicoverpa armigera (Lepidoptera: Noctuidae) in Australia. Journal of Economic Entomology 100(3), 894-894.

Men, X., Ge, F., Yardim, E.N. \& Parajulee, M.N. (2005) Behavioral response of Helicoverpa armigera (Lepidoptera: Noctuidae) to Cotton with and without expression of the CrylAc - endotoxin protein of Bacillus thuringiensis Berliner. Journal of Insect Behavior 18(1), 33-50. doi: 10.1007/s10905-005-9345-9.

Rochester, W.A., Zalucki, M.P., Ward, A., Miles, M. \& Murray, D.A.H. (2002) Testing insect movement theory-empirical analysis of pest data routinely collected from agricultural crops. Computers and Electronics in Agriculture 35(2), 139-149.

Sharma, H.C. (2005) Heliothis/Helicoverpa management: emerging trends and strategies for future research. pp. 453-463 in Sharma, H.C. (Ed) Heliothis/Helicoverpa Management: Emerging Trends and Strategies for Future Research Plymouth, UK, Enfield, NH, Science Publishers, Inc.

Tabashnik, B.E. \& Carrière, Y. (2010) Field-evolved resistance to Bt cotton: bollworm in the U.S. and pink bollworm in India. South Western Entomologist 35(3), 417-424. doi: 10.3958/ 059.035.0326.

Tabashnik, B.E., Dennehy, T.J. \& Carrière, Y. (2005) Delayed resistance to transgenic cotton in pink bollworm. Proceedings of the National Academy of Sciences of the United States of America 102(43), 15389-15393. doi: 10.1073/pnas.0507857102.

Tabashnik, B.E., Van Rensburg, J.B.J. \& Carrière, Y. (2009) Fieldevolved insect resistance to Bt crops: definition, theory, and data. Journal of Economic Entomology 102(6), 2011-2025. doi: 10.1603/029.102.0601.

Teakle, R.E. \& Jensen, J.M. (1985) Heliothis punctigera. pp. 312-322 in Singh, R. \& Moore, R.F. (Eds) Handbook of Insect Rearing, vol. 2. Amsterdam, Elsevier.

Torres, J.B. \& Ruberson, J.R. (2006) Spatial and temporal dynamics of oviposition behavior of bollworm and three of its predators in $\mathrm{Bt}$ and non-Bt cotton fields. Entomologia Experimentalis et Applicata 120(1), 11-22. doi: 10.1111/j.15707458.2006.00422.x.
Wilson, L., Downes, S., Khan, M., Whitehouse, M., Baker, G., Grundy, P. et al. (2013) IPM in the transgenic era: a review of the challenges from emerging pests in Australian cotton systems. Crop \& Pasture Science 64(8), 737-749.

Yang, Y., Johnson, M.L. \& Zalucki, M.P. (2008) Possible effect of genetically modified cotton on foraging habits of early instar Helicoverpa armigera (Hübner) (Lepidoptera: Noctuidae) larvae. Australian Journal of Entomology 47(2), 137-141. doi: 10.1111/j.1440-6055.2008.00640.x.

Zalucki, M.P., Daglish, G., Firempong, S. \& Twine, P. (1986) The biology and ecology of Heliothis armigera (Hübner) and Heliothis punctigera wallengren (Lepidoptera, Noctuidae) in Australia what do we know? Australian Journal of Zoology 34(6), 779-814.

Zalucki, M.P., Murray, D.A.H., Gregg, P.C., Fitt, G.P., Twine, P.H. \& Jones, C. (1994) Ecology of Helicoverpa armigera (Hübner) and Heliothis punctigera (Wallengren) in the Inland of Australia - larval sampling and host-plant relationships during winter and spring. Australian Journal of Zoology 42(3), 329-346.

Zalucki, M.P., Adamson, D. \& Furlong, M.J. (2009) The future of IPM: whither or wither? Australian Journal of Entomology 48 (2), 85-96. doi: 10.1111/j.1440-6055.2009.00690.x.

Zalucki, M.P., Cunningham, J.P., Downes, S., Ward, P., Lange, C., Meissle, M., Schellhorn, N.A. \& Zalucki, J.M. (2012) No evidence for change in oviposition behaviour of Helicoverpa armigera (Hübner) (Lepidoptera: Noctuidae) after widespread adoption of transgenic insecticidal cotton. Bulletin of Entomology Research 102(4), 1-9. doi: 10.1017/ S0007485311000848.

Zhang, H., Yin, W., Zhao, J., Jin, L., Yang, Y., Wu, S., Tabashnik, B.E.T. \& Wu, Y. (2011) Early warning of cotton bollworm resistance associated with intensive planting of Bt cotton in China. PloS ONE 6(8), e22874. doi: 10.1371/journal. pone.0022874.g001.

Zhao, D., Zalucki, M.P., Guo, R., Fang, Z., Shen, W., Zhang, L. \& Liu, B. (2016) Oviposition and feeding avoidance in Helicoverpa armigera (Hübner) against transgenic Bt cotton. Journal of Applied Entomology. doi: 10.1111/jen.12304. 